\title{
Investigation of the Capacitive Properties of Chemically Activated Sugarcane Bagasse Biochar for Supercapacitor Application
}

\author{
N. Bora ${ }^{1}$, V.K. Jayswal ${ }^{2}$, R. Kataki1,* \\ ${ }^{1}$ Biofuel Laboratory, Department of Energy, Tezpur University, Assam 784028, India \\ ${ }^{2}$ Département de chimie, Université Laval, Québec, QC, G1V 0A6, Canada
}

(Received 21 March 2021; revised manuscript received 15 June 2021; published online 25 June 2021)

\begin{abstract}
In this study, sugarcane bagasse, an abundantly available agro-industrial waste was pyrolyzed into biochar, and activated carbon was produced. Experiments were performed to evaluate the potential of activated biochar carbon as an electrode material in supercapacitor. $\mathrm{KOH}$ activated biochar carbon showed a higher surface area of $2336.45 \mathrm{~m}^{2} \mathrm{~g}-1$. Further electrochemical measurements of the activated carbon show that the material exhibited better performances compared to some of the reported carbon materials derived from biomass, that were utilized in supercapacitor electrodes. The activated carbon electrode showed a high specific capacitance of $197.33 \mathrm{~F} \cdot \mathrm{g}^{-1}$ at a scan rate of $1 \mathrm{mV} \cdot \mathrm{s}^{-1}$ in $1.5 \mathrm{M} \mathrm{KOH}$ electrolyte. Moreover, the electrode displayed good initial capacitance retention, which is $65 \%$ after 1000 cycles. The electrode prepared using non-activated biochar carbon exhibited poor performance and was not considered for any other electrochemical measurements except cyclic voltammetry. The maximum specific capacitance of the non-activated carbon electrode in cyclic voltammetry was found to be $13.88 \mathrm{~F} \cdot \mathrm{g}^{-1}$ at a scan rate of $1 \mathrm{mV} \cdot \mathrm{s}^{-}$ 1. The galvanostatic charge/discharge test of the activated biochar electrode displayed a better chargedischarge mechanism and the GCD curve slightly resembled the ideal triangular shape. Maximum energy and power densities shown by the electrode of activated carbon were $17.57 \mathrm{Wh} \cdot \mathrm{kg}^{-1}$ and $2.06 \mathrm{~kW} \cdot \mathrm{kg}^{-1}$. The high surface area of activated carbon having mesoporous structure is significant for this electrochemical characteristic of the prepared electrode. The study indicates that sugarcane bagasse has the potential to use it as raw material for the preparation of activated biochar carbon for its application in supercapacitor.
\end{abstract}

Keywords: Biomass, Biochar, Sugarcane bagasse, Activated carbon, Supercapacitor.

DOI: 10.21272/jnep.13(3).03025

PACS numbers: 88.20.D, 81.05.U

\section{INTRODUCTION}

Supercapacitor is an energy storage device that can store electrochemical energy following the principle of ion adsorption and desorption at electrode/electrolyte boundary. Out of the different supercapacitors, Electric Double Layer Capacitor (EDLC) is a significant one due to its high-power output, long cycle life, and rapid charge/discharge mechanism. The electrode material is significant for electrochemical performance and price of the supercapacitors [1-3]. Commercial activated carbon obtained from fossilbased resources is demonstrated as a suitable electrode material in supercapacitor applications because of its high porosity, specific surface area, cheaper cost, high availability, and electrochemical stability [4].

In this backdrop, the present study was conducted for exploring potential of the activated biochar carbon prepared from an agro-industrial waste (sugarcane bagasse) for EDLC type supercapacitor application. The study involves slow pyrolysis/carbonization for the preparation of biochar from sugarcane bagasse followed by a controlled chemical activation using $\mathrm{KOH}$ to synthesize activated biochar carbon. The activated carbon thus obtained was used for the preparation of electrodes. Electrodes were further subjected to electrochemical measurements viz. cyclic voltammetry (CV), and Galvanostatic Charge/Discharge (GCD) to understand the technical feasibility of the biochar as supercapacitor electrode material.

\section{MATERIALS AND METHODS}

\subsection{Materials}

Sugarcane bagasse was collected from a Jaggery making unit located near Tezpur University and grinded into fine powder and heated in hot air oven at $100{ }^{\circ} \mathrm{C}$ overnight. It was then sieved and samples less than $500 \mu \mathrm{m}$ were used. $\mathrm{KOH}$ (Merck) was used as a chemical activating agent and as an electrolyte. Fluorine doped Tin Oxide (FTO) glass was used as current collector and 0.5 wt. \% Nafion solution was used as binder for the construction of working electrode.

\subsection{Pyrolysis and Biochar Carbon Activation}

Sugarcane bagasse was pyrolyzed at $800^{\circ} \mathrm{C}$ for $2 \mathrm{~h}$ in a fixed bed pyrolizer in $\mathrm{N}_{2}$ atmosphere. The obtained biochar was denoted as NAB800 and was chemically treated using $\mathrm{KOH}$ in 3:1 ratio with the biochar. The chemically treated biochar again pyrolyzed maintaining the requisite temperature of $800{ }^{\circ} \mathrm{C}$ for $1 \mathrm{~h}$ and treated with hydrochloric acid $(\mathrm{HCl})$ and then washed using double deionized (DD) water to get neutral $\mathrm{pH}$. This activated sample was denoted as AB800. All the experiments were performed in $5{ }^{\circ} \mathrm{C} \cdot \mathrm{min}^{-1}$ heating rate.

\subsection{Characterization}

Field Emission Scanning Electron Microscopy (FESEM) was conducted in a Sigma, Zeiss FESEM

\footnotetext{
*rupam@tezu.ernet.in

The results were presented at the International Conference on Innovative Research in Renewable Energy Technologies (IRRET-2021)
} 
instrument. Powder X-ray Diffraction (PXRD) of $\mathrm{KOH}$ activated biochar carbon (AB800) and non-activated sample (NAB800) was analyzed using Rigaku miniflex diffractometer $(\mathrm{Cu}-\mathrm{K} a$ radiation, $\lambda=1.5406 \AA$ ) to evaluate the crystalline nature of prepared samples. Specific surface area of the prepared samples was determined by Brunauer-Emmett-Teller (BET) method. BarrettJoyner-Halenda (BJH) model was utilized in nature and density determination of porosity. For that purpose, NOVA 1000E, NOVA WIN, QUANTACHROME instrument was used. The degassing temperature in BET analysis was $150^{\circ} \mathrm{C}$.

\subsection{Electrochemical Evaluation}

The working electrodes of AB800 and NAB800 samples were fabricated for electrochemical measurements by mixing the carbon material with 0.5 wt. \% Nafion solution as a binder material and FTO glass as current collector. The ratio of carbon material to Nafion solution was taken as 10:1. For the preparation of working electrode, $6 \mathrm{mg}$ of bio-carbon and $0.6 \mathrm{ml}$ of Nafion solution were mixed and ultrasonicated for $1 \mathrm{~h}$ to obtain a homogenized mixture/slurry. The electrochemical experiments were performed in $1.5 \mathrm{M} \mathrm{KOH}$ aqueous electrolyte solution using the Bio-Logic SP-150 potentiostat.

The capacitance was calculated by the following equation (1):

$$
C\left(F g^{-1}\right)=\frac{\int_{V_{1}}^{V_{2}} I \mathrm{~d} V}{m v\left(V_{2}-V_{1}\right)}
$$

where $I$ (in A) is the current from CV curves, $m$ (in g) is the carbon mass, $v$ (in $\mathrm{Vs}^{-1}$ ) is the scan rate, $V_{1}$ and $V_{2}$ (in $\mathrm{V}$ ) are start and end potential limits, respectively.

EIS analysis of the activated carbon material was recorded within the frequency range $10 \mathrm{kHz}-0.1 \mathrm{~Hz}$ in 1.5 M KOH electrolyte solution. The alternating current amplitude taken for the analysis was $10 \mathrm{mV}$ in an open circuit potential, and. GCD tests were run conducted between -2 to $0.85 \mathrm{~V}$ at different current densities.

Energy $(E)$ and power densities $(P)$ were evaluated using equations (2) and (3):

$$
\begin{gathered}
E\left(\mathrm{Wh} . \mathrm{kg}^{-1}\right)=\frac{C_{\text {cell }} \cdot \Delta V^{2}}{2 * 3.6}, \\
P\left(\mathrm{~W} . \mathrm{kg}^{-1}\right)=\frac{3600 * E}{\Delta t},
\end{gathered}
$$

where $C$ denotes capacitance, $\Delta V$ (in $\mathrm{V}$ ) is the potential window, $\Delta t$ (in $\mathrm{s}$ ) is the discharge time.

\section{RESULTS AND DISCUSSION}

The FESEM analysis of AB800 and NAB800 was performed for determination of pore distribution and pore size of surface carbon before and after activation. After performing chemical activation, pore distribution of the biochar carbon increased by a large extent. Moreover, the size of the pores has also increased as evidenced from FESEM (Fig. 1a and Fig. 1b).

The PXRD spectra of NAB800 depicted a broad and weak peak within 20 to 30 deg range. The unavailability of any other peaks referred the lack of other compounds. In $\mathrm{AB} 800$, additionally, a broader and weaker peak occurred around 40 to $50 \mathrm{deg}$ which is directed towards the carbonization of material and existence of graphitic structure. It also signified the availability of amorphous structured carbon. Low angle scatter indicated the existence of larger pore distribution [5]. Fig. 1c shows the PXRD pattern of the samples.

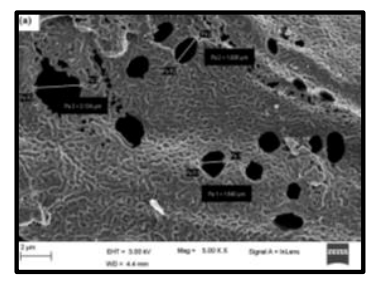

a

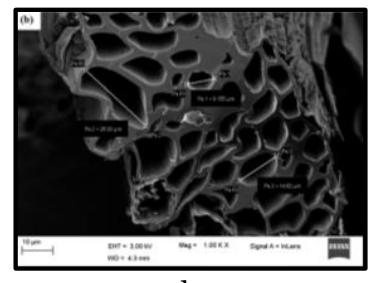

b

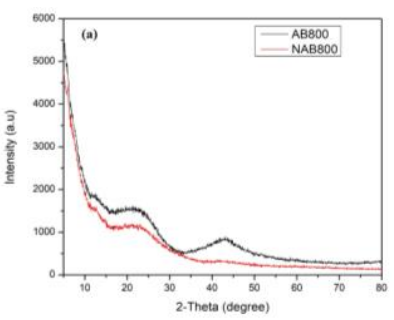

$\mathrm{C}$

Fig. 1 - FESEM images of NAB800 (a) and AB800 (b), PXRD patterns of $\mathrm{AB} 800$ and NAB800 (c)

BET analysis of the samples was conducted to determine the porous nature and surface area of biochar carbon. AB800 exhibited pores consisting mainly of mesoporous nature along with traces of macropores. The surface area $\left(S_{\mathrm{BET}}\right)$ and the mean pore size of AB800 were found to be $2336.45 \mathrm{~m}^{2} \cdot \mathrm{g}^{-1}$ and $61.22 \mathrm{~nm}$, respectively, and showed type IV nitrogen sorption isotherm. The curve clearly signified the high macroporosity of the sample. The pore size distribution calculated from the adsorption isotherms using BJH model is shown in Fig. $2 \mathrm{~b}$. The $S_{\text {BET }}$ and pore size of NAB800 were found to be $333.20 \mathrm{~m}^{2} \cdot \mathrm{g}^{-1}$ and $1.60 \mathrm{~nm}$, respectively. It also followed type IV nitrogen sorption isotherm and consists mainly of mesopores and some amount of macropores.

Cyclic voltammetry test was conducted within the potential range of $-0.2-0.85 \mathrm{~V}$ for determination of capacitance. NAB800 electrode showed very poor electrical conductivity and was not considered for further electrochemical measurement. NAB800 electrode showed the highest capacitance of $13.88 \mathrm{~F} \cdot \mathrm{g}^{-1}\left(1 \mathrm{mV} \cdot \mathrm{s}^{-1}\right.$ scan rate). Fig. $3 \mathrm{a}$ and Fig. $3 \mathrm{~b}$ display CV curves for NAB800 samples for the scan rate ranges from 1 to $50 \mathrm{mV} \cdot \mathrm{s}^{-1}$ and changes in specific capacitance in respect of scan rate change, respectively.

AB800 electrode showed good electrical conductivity and electric double layer capacitive feature. AB800 exhibited the maximum capacitance of $197.33 \mathrm{~F} \cdot \mathrm{g}^{-1}$ at 
$1 \mathrm{mV} \cdot \mathrm{s}^{-1}$. Table 1 tabulates the obtained capacitances for the applied scan rates for AB800 and NAB800. This maximum value of capacitance is comparable with previously reported value of specific capacitance from various biochar-based supercapacitor electrode (see Table 2). Fig. 3c and Fig. 3d depict the specific capacitances of AB800 sample, and capacitance change with respect to scan rate, respectively.

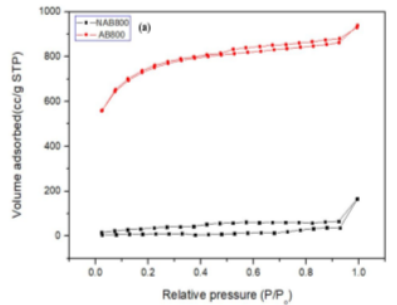

a

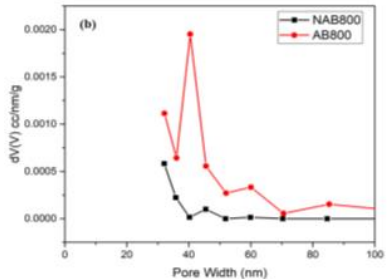

b

Fig. 2 - Nitrogen adsorption-desorption isotherms of AB800 and NAB800 at $77.35{ }^{\circ} \mathrm{C}$ (a), pore size distribution calculated from the adsorption isotherms using BJH Model (b)
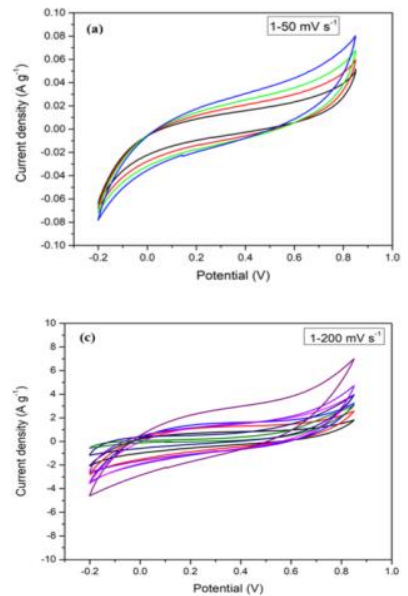

Fig. 3 - CV curves of NAB800 within $1-50 \mathrm{mV} \cdot \mathrm{s}^{-1}$ (a), rate performance of NAB800 within 1-50 mV·s ${ }^{-1}$ (b), CV curves of AB800 within 1-200 $\mathrm{mV} \cdot \mathrm{s}^{-1}(\mathrm{c})$, rate performance of $\mathrm{AB} 800$ within $1-200 \mathrm{mV} \cdot \mathrm{s}^{-1}(\mathrm{~d})$

To determine the initial capacitance retention of the AB800 sample electrode, it had undergone $1000 \mathrm{CV}$ cycles in the voltage range $-0.2-0.85 \mathrm{~V}$ at a scan rate of $100 \mathrm{mV} / \mathrm{s}$. Capacitance from the first cycle was $33.28 \mathrm{~F} \cdot \mathrm{g}^{-1}$ and that of the $1000^{\text {th }}$ cycle was $21.38 \mathrm{~F} \cdot \mathrm{g}^{-1}$. AB800 electrode showed a capacitance retention of $65 \%$. The CV curves before and after 1000 cycles has been shown in Fig. 4c.

Galvanostatic charge/discharge test was performed at current densities 0.5 and $0.1 \mathrm{~A} \cdot \mathrm{g}^{-1}$ for evaluating charging/discharge mechanism of AB800 electrode. The curve showed the reduction in charging and increase in discharging time, with increase in current density. In addition to that, it could be observed that time taken
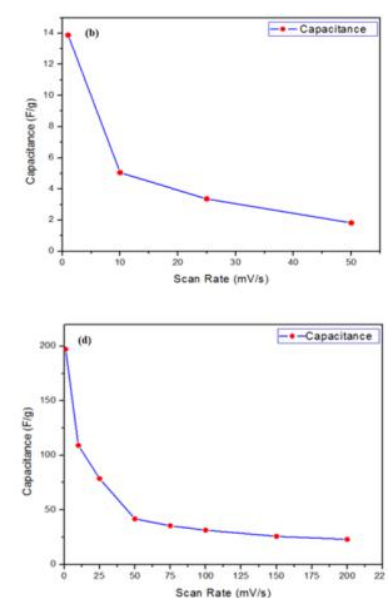

Table 1 - Specific capacitances of AB800 and NAB800

\begin{tabular}{|c|c|c|}
\hline $\begin{array}{c}\text { Scan rate } \\
\left(\mathbf{m V} \cdot \mathbf{s}^{-1} \mathbf{)}\right.\end{array}$ & $\begin{array}{c}\text { AB800 } \\
\left(\mathbf{F} \cdot \mathbf{g}^{-1} \mathbf{)}\right.\end{array}$ & $\begin{array}{c}\text { NAB800 } \\
\mathbf{( F \cdot g ^ { - 1 } \mathbf { ~ }}\end{array}$ \\
\hline 1 & 197.33 & 13.88 \\
\hline 10 & 109.20 & 5.05 \\
\hline 25 & 78.68 & 3.36 \\
\hline 50 & 41.75 & 1.82 \\
\hline 75 & 35.43 & - \\
\hline 100 & 31.44 & - \\
\hline 150 & 25.79 & - \\
\hline 200 & 22.98 & - \\
\hline
\end{tabular}

Table 2-Comparison of the properties of activated carbon prepared from various biomass feedstocks

\begin{tabular}{|c|c|c|c|c|}
\hline Biomass & $\begin{array}{c}\text { BET } \\
\text { surface } \\
\text { area } \\
\left(\mathbf{m}^{\mathbf{2}} \mathbf{g}^{-1}\right)\end{array}$ & $\begin{array}{c}\text { Specific } \\
\text { capacitance } \\
\left(\mathbf{F} \cdot \mathbf{g}^{-1}\right)\end{array}$ & Electrolyte & Reference \\
\hline $\begin{array}{c}\text { Pistachio } \\
\text { Nutshell }\end{array}$ & 1971 & 45 & $\begin{array}{c}1 \mathrm{M} \\
\text { Li-Salt }\end{array}$ & {$[7]$} \\
\hline $\begin{array}{c}\text { Rice } \\
\text { Husk }\end{array}$ & 2696 & 147 & $\begin{array}{c}6 \mathrm{M} \\
\mathrm{KOH}\end{array}$ & {$[8]$} \\
\hline Firewood & 1064 & 180 & $\begin{array}{c}0.5 \mathrm{M} \\
\mathrm{H}_{2} \mathrm{SO}_{4}\end{array}$ & {$[9]$} \\
\hline $\begin{array}{c}\text { Woody } \\
\text { Biochar }\end{array}$ & 990 & 167 & $\begin{array}{c}0.1 \mathrm{M} \\
\mathrm{NaCl}\end{array}$ & {$[10]$} \\
\hline $\begin{array}{c}\text { Sugarcane } \\
\text { Bagasse }\end{array}$ & 2336.45 & 197.33 & $\begin{array}{c}1.5 \mathrm{M} \\
\mathrm{KOH}\end{array}$ & This work \\
\hline
\end{tabular}

for charging was less compared to the discharging time (Fig. 4a). The GCD curves slightly resembled the ideal triangular shape.

The electrochemical impedance data were studied by means of Nyquist plot for displaying the frequency response characteristic of the electrode/electrolyte system. It was put between $Z^{\prime \prime}$, which is the imaginary component of the impedance, and $Z^{\prime}$ (real component). Fig. $4 \mathrm{~b}$ displays the Nyquist plot of AB800 electrode. Semicircle formation was observed at the higher frequency which was followed by linearity at low frequency (Fig. 4b, the inset). The formation of semicircle at higher frequency region signified the Faradaic process where charge movement taking place at the electrode/ 
electrolyte boundary. The slope of line at lower frequency area refers the electrolyte ion diffusivity nature of the electrode. Another aspect was the vertical line after the slope line which was closed to $90{ }^{\circ} \mathrm{C}$ signified the pure capacitive nature of the active carbon material as well as rapid transfer property of ions in the active carbon electrode [6].
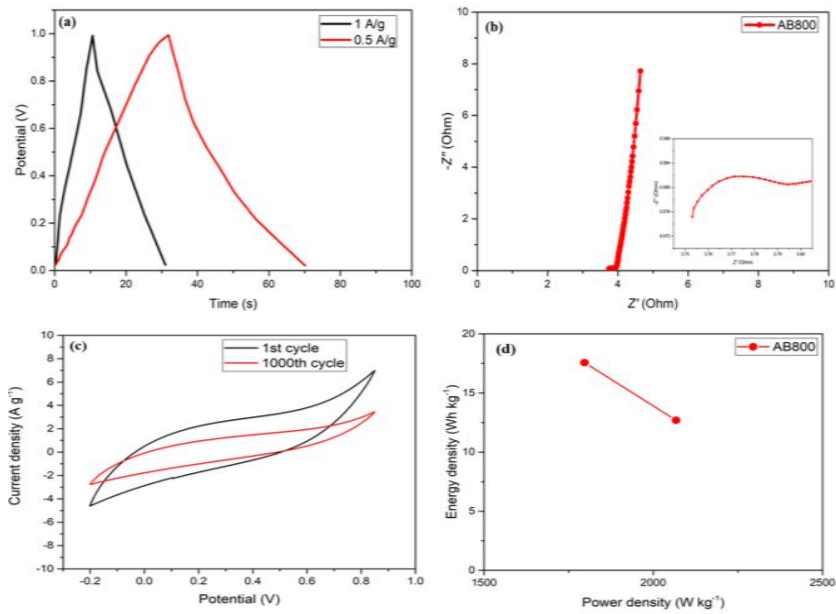

Fig. 4 - GCD curves for AB800 at 0.5 and $1 \mathrm{Ag}^{-1}$ (a), electrochemical impedance spectra of AB800 with the symmetrical cell represented as Nyquist plot (b), CV curves of 1000 cycles for AB800 (c), Ragone plot of energy vs power densities of AB800 electrode $(\mathrm{d})$

\section{CONCLUSIONS}

In summary, preparation of activated biochar carbon from sugarcane bagasse performing pyrolysis followed by $\mathrm{KOH}$ activation for supercapacitor application appears to be technically feasible. As sugarcane bagasse is widely available, cheap, and sustainable agro-industrial waste, production of activated carbon can be done industrially in large-scale. The resultant activated carbon displays high specific surface area with moderate mesoporous pore distribution, due to which the activated carbon demonstrates excellent electrochemical performances in aqueous electrolyte.
The relation between energy densities and power densities for the AB800 sample is shown in Ragone plot (Fig. 4d). Maximum energy density and power density without considering ESR (Equivalent Series Resistance) obtained for AB800 were 17.57 and $2.06 \mathrm{~kW} \cdot \mathrm{kg}^{-1}$, respectively, using $1.5 \mathrm{M} \mathrm{KOH}$ electrolyte.

\title{
REFERENCES
}

1. J.A. Van Aardenne, F.J. Dentener, J.G.J. Olivier, C.K. Goldewijk, J. Lelieveld, Global Biogeochem. Cy. 15 No 4, 909 (2001).

2. S. Searle, C. Malins, Gcb Bioenerg. 7(2), $328(2015)$.

3. P. Kalyani, A. Anitha, Int. J. Hydrogen Energ. 38, 4034 (2013).

4. S.I. Wei-Jiang, W.U. Xiao-Zhong, X. Wei, Z. Jin, Z. Shu-Ping, J. Inorg. Mater. 1 (2011).

5. K.H. Kim, J.Y. Kim, T.S. Cho, J.W. Choi, Bioresource Technol. 118, 158 (2012).

6. C. Peng, X. Yan, R. Wang, J. Lang, Y. Ou, Q. Xue, Electrochim. Acta 87, 401 (2013).

These indicate that the carbon material from sugarcane bagasse could be a promising biomass source for supercapacitors and other energy storage devices.

\section{ACKNOWLEDGEMENTS}

The work was financially supported by the University of Tezpur under Innovation and Research Grant (No. TU/Fin/R/18-19/339). The first author gratefully acknowledges the financial grant in the form of National Doctoral Fellowship (NDF), from AICTE, New Delhi, India.

\section{Дослідження ємнісних властивостей хімічно активованого біовугілля з жому цукрової тростини для застосування в суперконденсаторах}

\author{
N. Bora ${ }^{1}$, V.K. Jayswal ${ }^{2}$, R. Kataki ${ }^{1}$ \\ ${ }^{1}$ Biofuel Laboratory, Department of Energy, Tezpur University, Assam 784028, India \\ 2 Département de chimie, Université Laval, Québec, QC, G1V 0A6, Canada
}


У дослідженні жом цукрової тростини, що е широко доступним агропромисловим відходом, був піролізований у біовугілля, отримуючи, таким чином, активоване вугілля. Були проведені експерименти для оцінки потенціалу активованого біовугілля як електродного матеріалу для суперконденсаторів. Біовугілля, активоване КОН, показало більшу площу поверхні 2336,45 $\mathrm{m}^{2} \Gamma^{-1}$. Подальші електрохімічні вимірювання активованого вугілля виявили найкращі характеристики матеріалу в порівнянні з деякими із зазначених вуглецевих матеріалів, вироблених з біомаси, які використовувалися в електродах суперконденсаторів. Електрод з активованого вугілля показав високу питому емність 197,33 Ф·Г- ${ }^{-1}$ при швидкості сканування $1 \mathrm{mB} \cdot \mathrm{c}^{-1}$ в $1,5 \mathrm{M}$ електроліті КОН. Крім того, електрод продемонстрував гарне збереження початкової емності, яка становить 65 \% після 1000 циклів. Електрод, отриманий з використанням неактивованого біовугілля, показав погані характеристики і не розглядався для будь-яких інших електрохімічних вимірювань, крім циклічної вольтамперометрії. Максимальна питома емність електрода 3 неактивованого вугілля при циклічній вольтамперометрії виявилася рівною $13,88 \Phi \cdot \Gamma^{-1}$ при швидкості сканування $1 \mathrm{MB} \cdot \mathrm{c}^{-1}$. Тест гальваностатичного заряду/розряду (GCD) електрода з активованого біовугілля показав кращий механізм заряду/розряду, а крива GCD трохи нагадувала ідеальну трикутну форму. Максимальні щільності енергії та потужності, продемонстровані електродом з активованого вугілля, становили відповідно 17,57 Вт.год·кг ${ }^{-1}$ та 2,06 кВт·кг ${ }^{-1}$. Велика площа поверхні активованого вугілля, що має мезопористу структуру, є важливою електрохімічною характеристикою виготовленого електрода. Дослідження показуе, що жом цукрової тростини потенційно може використовуватися як сировина для приготування активованого біовугілля для його застосування в суперконденсаторах.

Ключові слова: Біомаса, Біовугілля, Жом цукрової тростини, Активоване вугілля, Суперконденсатор. 